Summer 2011

\title{
Obstacles to Accessing the State Justice System in Rural Afghanistan
}

Kara Jensen

Indiana University Maurer School of Law, karajens@indiana.edu

Follow this and additional works at: https://www.repository.law.indiana.edu/ijgls

Part of the Comparative and Foreign Law Commons

\section{Recommended Citation}

Jensen, Kara (2011) "Obstacles to Accessing the State Justice System in Rural Afghanistan," Indiana Journal of Global Legal Studies: Vol. 18 : Iss. 2 , Article 11.

Available at: https://www.repository.law.indiana.edu/ijgls/vol18/iss2/11

This Note is brought to you for free and open access by the Law School Journals at Digital Repository @ Maurer Law. It has been accepted for inclusion in Indiana Journal of Global Legal Studies by an authorized editor of Digital Repository@Maurer Law. For more information, please contactrvaughan@indiana.edu.

\section{$\Psi$}

JEROME HALL LAW LIBRARY

INDIANA UNIVERSITY

Maurer School of Law
Blooming ton 


\title{
Obstacles to Accessing the State Justice System in Rural Afghanistan
}

\author{
KARA JENSEN ${ }^{*}$
}

\begin{abstract}
The United States' mission in Afghanistan is to create a stable, democratic country that will no longer serve as a stronghold for terrorist organizations. Since the U.S. takeover in 2001, most rule-of-law promotion has focused on urban centers, allowing the Taliban to gain traction in rural areas by creating its own alternative justice system. This Note discusses the primary obstacles preventing citizens in rural Afghanistan from accessing the state justice system and suggests solutions to those obstacles.
\end{abstract}

\section{INTRODUCTION}

Most scholarship on rule of law promotion focuses on urban centers while largely ignoring rural areas. This is an oversight, because rule of law promoters face different obstacles to creating a rule of law culture in rural areas than in urban centers. Overlooking the unique challenges to rule of law promotion in rural areas can impede attempts to establish a nationwide rule of law culture in developing nations. Nowhere is this truer than in Afghanistan, where a historically wide gap between the center and periphery, combined with a population distribution that is three-quarters rural, makes the differences between rule of law promotion in rural and urban areas particularly relevant.

This Note will examine the cultural, practical, and physical obstacles to rural Afghans' access to the state justice system. It will analyze and present solutions to the three primary obstacles to access: low education levels among Afghan citizens, police, and the judiciary; a pervasive cultural distrust of state institutions on the part of rural Afghans stemming from historical and contemporary circumstance; and

* Notes Editor, Indiana Journal of Global Legal Studies; J.D., 2011, Indiana University Maurer School of Law; B.A., 2008, Purdue University. Many thanks to David Williams and Feisal Istrabadi for their guidance in the creation of this Note

Indiana Journal of Global Legal Studies Vol. 18 \#2 (Summer 2011)

(C) Indiana University Maurer School of Law 
the dangers and difficulties that rural Afghans face in traveling to centralized court locations.

Much of the work needed to dismantle these obstacles must be done by the international community. While the international community has been heavily involved in rebuilding Afghanistan's justice system, its work has been disorganized, inefficient, at times counterproductive, and mostly focused on the urban centers. Many of the recommendations made in this Note focus on how donor countries can use their resources more efficiently and effectively. Most important, though, is the need for the international community to wrest its attention away from Kabul and Kandahar and make a concerted effort to improve the court system in the provinces, especially in light of reports that the Taliban has begun operating Taliban courts in the absence of a functioning state judicial system. ${ }^{1}$ Through these courts, as well as through "redress committees" where citizens can complain about Taliban behavior, the Taliban is providing a model for fair and effective government in the provinces. $^{2}$ The international community should not forget that the Taliban's first rise to power was based on its ability to provide safety and order for rural Afghans when the official state government proved unable to do so.

In analyzing access to justice in rural Afghanistan, this Note will not only discuss the court system, but also the police. The police are the entry point to the state justice system for the victims of crimes, and access to the police is just as important as access to the judiciary in a country under the rule of law. ${ }^{3}$ Police reform without judicial reform can be counterproductive, and the same can be said of judicial reform without police reform. ${ }^{4}$ In Afghanistan, police reform and judicial reform have been particularly fragmented, to the detriment of both areas. This fragmentation is largely due to the lead nation framework established by the international community as a means of dividing global responsibility for the rebuilding of Afghanistan. Under the lead nation framework, different nations undertook responsibility for police and

1. See Kim Barker, Letter from Kabul: Solving Afghanistan's Problems, FoREIGN AFF. (Nov. 30, 2009), http://www.foreignaffairs.com/features/letters-from/letter-from-kabul-solvingafghanistans-problems (These courts have primarily been operating in areas where the state justice system is inaccessible and corrupt, and the community dispute resolution systems have been co-opted by local warlords.).

2. See id.

3. See Rachel Kleinfeld, Competing Definitions of the Rule of Law, in PROMOTING THE RULE OF LAW ABROAD: IN SEARCH OF KNOWLEDGE 31, 54 (Thomas Carothers ed., 2006).

4. Id. at 55 . 
judicial system reform, which has undermined the effectiveness of both reform projects. ${ }^{5}$

This Note only briefly touches on statutory law reform because it has less of a direct impact on rural Afghans' access to justice. Most judges in rural Afghanistan do not look to statutory law while making decisions, either because they do not have access to it or because they are unfamiliar with the application of statutory law and highly suspicious of it. Statutory law reform will not have an impact until the justice system is reformed to ensure that the statutory law is applied.

Transitional justice systems in Afghanistan have taken a back seat to political realities, as there is very little political will on the national or international level to look into crimes that occurred during the decades-long war that has ravaged Afghanistan. ${ }^{6}$ According to one Afghan official, a serious effort to pursue transitional justice "could implicate half the current cabinet."7 A participant in the United States Institute of Peace's Afghanistan Working Group pointed out that for the past twenty years "everybody who was exercising power was a war criminal in one way or another because there wasn't any other way to exercise power." 8 Because no transitional justice systems are currently in the works, this Note will not discuss transitional justice.

\section{BACKGROUND}

The events of September 11, 2001, demonstrated to the international community that in our globalized modern world, the failure of even one underdeveloped state could have security implications for the rest of the world. The Taliban rose to power in Afghanistan because it was the only group providing order and stability in what was essentially an anarchic state following the collapse of the Soviet Union and the subsequent failure of the Najibullah regime. ${ }^{9}$ United States' success in Afghanistan is therefore contingent not only on a military victory over the Taliban, but also on the successful establishment of a new, democratic government. A justice system is one

5. ANDREW WILDER, CoPs oR RoBbers?: THE STRUgGle to Reform the AFGHAN NATIONAL POLICE, at $\mathrm{x}$ (2007), available at http://www.areu.org.af/index.php? option=com_docman\&Itemid=\&task=doc_download\&gid=523.

6. Id. at xi.

7. U.S. InSt. OF PEACE, SPECIAL REPORT No. 117, ESTABLISHING THE RULE OF LAW IN AFGHANISTAN 12 (2004) [hereinafter ESTABLISHING THE RULE OF LAW].

8. U.S. INST. OF PEACE, SPECIAL RePoRt No. 105, Unfinished Business in AFGHANISTAN: WARLORDISM, RECONSTRUCTION, AND ETHNIC HARMONY 5 (2003) [hereinafter WARLORDSIM].

9. See generally StePHen TANner, Afghanistan: A MILITARY History From ALEXANDER THE GREAT TO THE FALL OF THE TALIBAN (2002). 
of the most essential building blocks of a successful, stable government. Thus, the United States and its allies cannot win in Afghanistan without making the creation of a functional justice system a priority.

\section{A. The Bonn Agreement and Lead Nation Status}

In December of 2001, representatives of industrialized nations and members of the Afghan Diaspora met in Bonn, Germany, to plan for the reconstruction of Afghanistan. The result of this conference was the Bonn Agreement, which established the political structure of postTaliban Afghanistan. ${ }^{10}$ Donor countries agreed to take responsibility (termed "lead nation" status) for different aspects of the rebuilding process. ${ }^{11}$ The United States, along with the United Kingdom and France, took responsibility for training the new national army; Italy took responsibility for judicial reform; and Germany took responsibility for police reform. ${ }^{12}$ However, the United States has since committed itself extensively to most aspects of the rebuilding process; it is the second largest donor to the justice sector and has also undertaken major initiatives in the sector of police reform. ${ }^{13}$

\section{B. The Afghan Judicial System}

The legal structure of the judicial system in Afghanistan is set out in the 2004 Constitution, which affirmed the liberal 1964 Constitution with few changes. ${ }^{14}$ Under the Constitution, the judiciary is an independent branch headed by the Supreme Court, which administers the lower courts and nominates candidates for judicial appointments, whose nominations must be confirmed by the president. ${ }^{15}$ The Supreme Court is also responsible for drawing up and implementing a budget for

10. See Agreement on Provisional Arrangements in Afghanistan Pending the ReEstablishment of Permanent Government Institutions, U.N. Doc. S/2001/1154 (Dec. 5, 2001) [hereinafter Bonn Agreement], available at http://www.unhcr.org/refworld/ docid/3f48f4754.html (providing for the establishment of the Afghan Interim Authority and requiring that free and fair elections be held and a Constitutional Loya Jirga be convened within specified time periods).

11. Faiz Ahmed, Note, Judicial Reform in Afghanistan: A Case Study in the New Criminal Procedure Code, 29 HASTINGS INT'L \& CoMP. L. REv. 93, 100-01 (2005).

12. Id. at 101.

13. ESTABLISHING THE RULE OF LAW, supra note 7, at 11-12, 16.

14. J. Alexander Thier, Reestablishing the Judicial System in Afghanistan 5-6 (Ctr. on Democracy, Dev. \& the Rule of Law, Working Paper No. 19, 2004), available at http://iisdb.stanford.edu/pubs/20714/Reestablishing_the_Judiciary_in_Afghanistan.pdf.

15. ConST. OF AFG. (2004) art. 132. 
the judiciary, in consultation with the government.16 Under the Supreme Court are the High Courts, which function as courts of appeal, and under them are the Primary Courts. ${ }^{17}$ The Supreme Court also has oversight authority to investigate abuse and corruption in the lower courts. ${ }^{18}$ Although one of the duties of the Supreme Court is to assess the constitutionality of all laws passed in Afghanistan, it has been criticized for violating the substantive provisions of the Constitution. ${ }^{19}$

Until recently, the Supreme Court was dominated by its very conservative Chief Justice, Faisal Ahmad Shinwari. ${ }^{20}$ In 2006, the parliament rejected his reappointment by President Karzai, partially due to concerns that Shinwari did not have the education required by the Constitution to serve on the Supreme Court. ${ }^{21}$ Among the controversial decisions made by the Court while Shinwari was the Chief Justice were attempts to ban cable television, women singing on television, and coeducation of male and female students, all without any legal basis to do so. ${ }^{22}$ The court was also criticized for appointing unqualified judges in an attempt to politicize the judiciary. In 2003, the court reported to Amnesty International that it had appointed 137 judges to the Supreme Court, when the size of the Supreme Court was constitutionally limited to nine members. ${ }^{23}$ In 2006 , a number of more moderate justices were appointed to the Supreme Court. Together with the new Chief Justice, Abdul Salam Azimi, they made the court much more moderate. ${ }^{24}$ The new court has made attempts to reform and institute standards and accountability in the lower courts. ${ }^{25}$

\section{The Customary Legal System}

While the state justice system has a monopoly in urban regions, it faces competition in villages and rural areas, where crimes and other

16. Id. art. 125.

17. Katherine McCullough, Out with the Old and in With the New: The Long Struggle for Judicial Reform in Afghanistan, 19 GEO. J. LEGAL ETHICS 821, 825 (2006).

18. Amnesty Int'l, Afghanistan: Re-establishing the Rule of Law, AI Index: ASA 11/021/2003, at 21 (Aug. 14, 2003).

19. See Thier, supra note 14 , at 1.

20. $I d$.

21. See Kim Barker, Op-Ed., At the Supreme Court, an Unlikely New Hero, CHI. TRIB., Jan. 21, 2007, at 5, available at http://www.chicagotribune.com/news/opinion/chi0701210351jan21,0,7944559.story.

22. See Thier, supra note 14 , at 1.

23. Amnesty Int'l, supra note 18, at 12 .

24. Ran Hirschl, The Theocratic Challenge to Constitution Drafting in Post-Conflict States, 49 WM. \& MARY L. REV. 1179, 1205 (2008).

25. Barker, supra note 21. 
disputes are traditionally handled under tribal or customary law. ${ }^{26}$ There is a history of conflict in Afghanistan between customary law, the state legal system, and Shari'a law. ${ }^{27}$ Rural Afghans have historically resisted the imposition of outside laws by the central government, regardless of whether the law was Shari'a law or the modern, Westernstyle law that led to the revolts against King Amanullah in 1924 and 1928.28

Customary law is "the means by which local communities resolve disputes . . based on a common cultural and ethical code that generates binding rules on its members." 29 Under the customary legal system, disputes are resolved by a jirga, a group of impartial men in the community known for their wisdom and ability to make decisions. ${ }^{30}$ The jirga seeks to resolve disputes through the use of mediation and arbitration; its power of coercive enforcement is limited, but threats to go to the state legal system are often used to force participants to abide by the decisions of the jirga. ${ }^{31}$

Customary law in Afghanistan is not based on retributive justice in the way that Western legal systems are, where the perpetrator of a crime is sent to prison. Instead, it is based on restorative justice, where the focus of the law is on making the victim whole and making the offender publically accountable for his deeds. ${ }^{32}$ Although unwritten, the Pashtunwali is a type of common law system, and the guidelines for

26. Thomas J. Barfield, On Local Justice and Culture in Post-Taliban Afghanistan, 17 CONN. J. INT'L L. 437, 440 (2002) [hereinafter Barfield, On Local Justice].

27. Thomas J. Barfield, Culture and Custom in Nation-Building: Law in Afghanistan, 60 ME. L. REv. 347, 351 (2008) [hereinafter Barfield, Culture and Custom].

28 Thomas J. Barfield, An Islamic State Is a State Run by Good Muslims: Religion as a Way of Life and Not an Ideology in Afghanistan, in REMAKING MusLIM POLITICS: PluRALISM, CONTESTATION, DEMOCRATIZATION 213, 218-20 (Robert W. Hefner ed., 2005) [hereinafter Barfield, $A$ State Run by Good Muslims] ("[R]ural revolts against changes in the legal status of women ... would be decried as un-Islamic. But the same people studiously ignored complaints by orthodox clergy that many of their own tribal customs ... violated shari'a law.").

29. Barfield, Culture and Custom, supra note 27, at 351. While each of the many different ethnic groups in Afghanistan has their own customary legal codes, the most common is the Pashtunwali, the Pashtun code of conduct. Id. at 352.

30. INT'L LEGAL FOUND., THE CUSTOMARY LAWS OF AFGHANISTAN 8 (2004), available at http://www.theilf.org/reports/ILF_Customary_Laws_of_Afghanistan.pdf [hereinafter ILF Report].

31. Christina Jones-Pauly \& Neamat Nojumi, Balancing Relations Between Society and State: Legal Steps Toward National Reconciliation and Reconstruction of Afghanistan, 52 AM. JUR. COMP. L. 825, 839-40 (2004).

32. E.g., ILF Report, supra note 30, at 10; Barfield, Culture and Custom, supra note 27, at 357 . 
setting compensation and assessing property damages are highly sophisticated. ${ }^{33}$

In many countries where a state government developed while tribal allegiances remained in place, there remains an uneasy truce between customary law, which is usually unwritten and mediation-based, and the law imposed by the new state government. Rwanda is one of the best examples of a country in which state-based law and customary law coexist. In Rwanda, the written Belgian law introduced during the colonial period and the unwritten customary law have evolved parallel to one another, and both continue to have significant force in Rwanda today. ${ }^{34}$ In the past few years, the United States has come to recognize the importance of customary legal systems in rural Afghanistan, and recent initiatives seek to take advantage of the stability of the traditional justice system. ${ }^{35}$ Hopefully this will serve as the first step in reconciling state-based law and customary law.

The customary legal systems in Afghanistan cannot be ignored by rule of law promoters. Attempts to expand the court system into the provinces must take into account the fact that it will not be filling a vacuum but operating side-by-side with a dispute resolution system that has been in place for a millennium. A cohesive and coordinating way of reconciling the two systems, such as that in use in Rwanda, must be developed in Afghanistan.

\section{The Challenge of Warlordism}

One of the foremost challenges facing Afghanistan today is the presence of a multitude of independent, private armies controlled by regional warlords. ${ }^{36}$ The United States Institute for Peace defines a warlord as "an individual who exercises a combination of military, political, and economic power outside a constitutional or legal framework." 37 In Afghanistan, the most senior warlords will serve as provincial governors or in other official positions, but they are not

33. See Barfield, Culture and Custom, supra note 27, at 356.

34. Laurel L. Rose, Women's Land Access in Post-Conflict Rwanda: Bridging the Gap Between Customary Land Law and Pending Land Legislation, 13 TEX. J. WOMEN \& L. 197, 203 (2004).

35. See, e.g., U.S. DEPARTMENT OF STATE, OFFICE OF THE SPECIAL REPRESENTATIVE FOR afghanistan and Pakistan, Afghanistan and Pakistan Regional Stabilization STRATEGY vi (2010).

36. M. Cherif Bassiouni, Report of the Independent Expert of the Commission on Human Rights on the Situation of Human Rights in Afghanistan, I 6, delivered to the General Assembly, U.N. Doc. A/59/370 (Sept. 21, 2004) [hereinafter Report of the Independent Expert]; see also ESTABLISHING THE RULE OF LAW, supra note 7, at 15.

37. See WARLORDISM, supra note 8 , at 3. 
accountable to the central government in Kabul. ${ }^{38}$ They pay for their private armies through a combination of extortion and narcotics smuggling. ${ }^{39}$

Coalition forces originally tried to work with the regional warlords to defeat the Taliban and pursue al-Qaida, and they provided the warlords with financial support. ${ }^{40}$ This gave the warlords time and money, allowing them to reemerge as significant power brokers. ${ }^{41}$ The private armies that resulted are now one of the greatest threats to human rights in Afghanistan. ${ }^{42}$ Most human rights violations and crimes in Afghanistan are committed by militia members, who are protected from prosecution because their commander is more powerful than the local representatives of the state justice system. ${ }^{43}$ The police in rural areas are often aligned with the local militia, so there is no state force available to protect the populace from the ravages of the militias. ${ }^{44}$ As a result, most villages chose to undertake their own security measures, often allying with several other villages in mutual defense agreements. ${ }^{45}$ Afghanistan will never be a rule of law society as long as a multitude of armed groups roam the countryside, skirmishing with each other over territory and border crossings, and co-opting state institutions for their own benefit.

\section{LACK OF EDUCATION}

The lack of qualified personnel is an enormous problem for Afghan reconstruction in general, but it is especially acute in the justice system. ${ }^{46}$ Most judges are unqualified for their positions because they have little to no legal education, ${ }^{47}$ and literacy rates in the police force correspond with the $28 \%$ literacy rate in the general population. 48 The lack of education makes training programs for both groups difficult.

38. See Establishing the RULE Of LAW, supra note 7, at 15; McCollough, supra note 17 , at 842 .

39. See EsTABlishing THE RULE OF LAW, supra note 7, at 15.

40. Id.; see also Report of the Independent Expert, supra note 36, I 7.

41. See ESTABLISHING THE RULE OF LAW, supra note 7, at 15; Report of the Independent Expert, supra note 36, II 7.

42. Report of the Independent Expert, supra note 36, ๆ 6.

43. Id.; FEINSTEIN INT'L Famine CTR., Human SECURITY AND LIVElihoods of RURAL AFGHANS, 2002-2003, at 50 (2004) [hereinafter FEINSTEIN], available at https:/wikis.uit.tufts.edu/confluence/display/FIC/Human + Security+and + Livelihoods + of $+R$ ural+Afghans.

44. FeInStein, supra note 43 , at 51 .

45. Id. at 49 .

46. See ESTABLISHING THE RULE OF LAW, supra note 7, at 7.

47. See infra notes 49-51.

48. See infra note 67. 
Trainees often don't understand the basic concepts underlying a civilian-based justice system, and training programs struggle to impart these basic concepts while also providing practical skills-based training. Finally, the lack of education in the general public means that many members of the public are unaware of what resources the judicial system has to offer or how to take advantage of these resources.

\section{A. The Judiciary}

Until recently, many members of the Supreme Court were not qualified under the constitutional provision requiring that they "have higher education in legal studies or in Islamic jurisprudence, and have sufficient expertise and experience in the judicial system of Afghanistan." 49 The situation is the same in the lower courts. Under Afghan law all judges must have a degree from the Faculty of Law or the Faculty of Shari'a and have completed a one-year professional training program..$^{50}$ However, in 2007, only two-thirds of judges had a secondary or legal education. ${ }^{51}$ The vast majority of judges with legal education were trained only in Islamic law and had little or no experience with statutory law or Western legal reasoning. ${ }^{52}$

Judicial reform in Afghanistan has been marked by interagency hostility and the lack of a cohesive strategy for reforming the justice sector. ${ }^{53}$ While the need for both judicial training and higher legal education is widely recognized, a lack of funding and vision means that legal training programs have been limited, especially in comparison to police training programs. ${ }^{54}$ Most programs have been short-term, inservice programs meant to train sitting judges. ${ }^{55}$.

The most prominent judicial training program was developed by $M$. Cherif Bassiouni, a widely known expert on international law and

49. CONST. OF AFG. (2004) art. 118; see also Amnesty Int'l, supra note 18, at 12; Kenneth Katzman, Cong. Research Serv., RS21922, AFghanistan, Politics, EleCtIONS, AND GOVERnMENT PERFORMANCE 3 (2009), available at http://www.fas.org/ sgp/crs/row/RS21922.pdf.

50. Sheila Reed, Conner foley \& Hamayoun Hamed, IDlo Monttoring and EvalUATION UNIT, IDLO ITALIAN FUNDED PROJECTS (2005-2008) FOR LEGAL AND JUDICLAL REFORM IN AFGHANISTAN: EVALUATION REPORT 17 (2008), available at http://www.idlo.int/DOCNEWS/277DOC1.pdf.

51. ASTRI SUHRKE \& KAJA BORChGREVINK, Negotiating JUSTICE SECTOR REFoRM IN AFGHANISTAN 220 (2008), available at http://www.humansecuritygateway.com/documents/ CMI_Afghanistan_NegotiatingJusticeSectorRefrom.pdf.

52. Id.

53. See ESTABlishing THE RULE of LAW, supra note 7, at 9.

54. Id.

55. Id. 
Islamic law, trained in Shari'a law, who has extensive experience in training judges in Islamic countries. The Judicial Reform Commission also runs a major training program that lasts nine months and has trained hundreds of judges and prosecutors. ${ }^{56} \mathrm{~A}$ number of other organizations have also developed training programs, but the programs have been ad hoc and little effort at coordination has been made. ${ }^{77}$ Few efforts have been made to rebuild the long-term legal education infrastructure. 58

A number of factors stand in the way of effective judicial training. Many judges, especially senior judges, are resistant to new techniques and are opposed to statutory law; they frequently express the opinion that all relevant law comes from the Koran. ${ }^{59}$ Judges also have vastly different levels of education and experience, which makes uniform training programs difficult to administer.60 Most judges have no experience in producing written opinions, are unfamiliar with having defense attorneys in their courtrooms, and are used to making decisions without reference to the statutory law. ${ }^{61}$ The basic idea that judges should make decisions based on the law is the key concept imparted in most training programs. ${ }^{62}$ Finally, the programs suffer from a lack of trained interpreters familiar with legal language, which is often complex and difficult to translate. ${ }^{63}$

One of the primary problems facing judicial training programs in Afghanistan is a lack of cohesiveness. Immediate reforms should focus on improving coordination and communication between the multitudes of different organizations providing training to judges. In order to do this, a centralized institution for judicial training should be created. This organization would provide the many groups administering programs the opportunity to coordinate those programs. This would prevent programs from overlapping and allow donor money to be used more efficiently. Such an organization would also be able to provide information about all of the judicial training programs to judges and other legal professionals, making it easier for judges to find a training program that meets their needs.

Donor countries should also begin to focus more heavily on longterm solutions to the dearth of legal professionals in Afghanistan by

\footnotetext{
56. See id. at 10; McCullough, supra note 17 , at 838 n.160.

57. REED ET AL., supra note 50, at 17.

58. ESTABLISHING THE RULE OF LAW, supra note 7, at 9 .

59. McCullough, supra note 17 , at 839 .

60. See id.

61. ESTABLISHING THE RULE OF LAW, supra note 7, at 10.

62. Id.

63. Id.
} 
providing aid to legal education and law schools. Improving legal education in a post-conflict country is an extremely important and often overlooked part of rule of law operations. Because currently sitting judges are often not interested in reform, the best hope for judicial reform is in the next generation of legal professionals. ${ }^{64}$ The decades of war were extremely destructive to Afghanistan's primary legal educational institution at Kabul University. ${ }^{65}$ Donor aid is needed to rebuild the institutional capacity of the law school, and the assistance of the international community of law professors is needed to update the curriculum.

\section{B. The Police}

Although the international community has spent over $\$ 10$ billion on police assistance programs, the Afghan National Police remain "the weak link in the security chain." 66 One of the primary challenges facing the police force is low education levels and lack of training. Most police officers are either illiterate or semi-literate. ${ }^{67}$ The inability to read and write makes it difficult for the police to perform basic police tasks such as writing incident reports, taking statements, and maintaining records. ${ }^{68}$ Low literacy rates have also diminished the effectiveness of the training programs created by the United States and Germany because participants have trouble learning and retaining information. ${ }^{69}$

Until 2005, police training was the primary focus of police reform efforts. 70 In August of 2002, Germany, the "lead nation" for police reform, opened a rebuilt Kabul Police Academy. ${ }^{71}$ The Academy offered two primary courses, one meant to provide a university-level education for commissioned officers and a shorter course meant to provide basic training for noncommissioned officers. ${ }^{72}$ The Academy also offered

64. See Richard Sannerholm, Legal, Judicial and Administrative Reforms in PostConflict Societies: Beyond the Rule of Law Template, 12 J. CONFLICT \& SECURITY L. 65, 83 (2007).

65. See McCullough, supra note 17 , at 840 .

66. See Robert M. PERITO, U.S. InSt. OF PEACE, SPecial Report No. 227, AFGHANistan's POLICE: THE WEAK LINK IN SECURITY SECTOR REFORM 1-2 (2009).

67. Id. at 3-4. Approximately $70-90 \%$ of the men in Afghanistan's police force in 2002 were illiterate, which is consistent with Afghanistan's national literacy rate of $28 \%$. However, in the provinces, illiteracy might be even worse. For example, of the 887 graduates of the Regional Training Center in Kunduz between January and November of 2006, only seven were literate. See WIIDER, supra note 5, at 30.

68. WILDER, supra note 5, at viii; PERITO, supra note 66, at 4.

69. WILDER, supra note 5, at viii; PERITO, supra note 66, at 4.

70. WILDER, supra note 5, at 29.

71. PERITO, supra note 66 , at 3.

72. Id.; WILDER, supra note 5, at 29. 
several shorter courses on specific subjects, such as counter-narcotics. ${ }^{73}$ While of high quality, the program was incapable of meeting the Interim Authority's goal of 70,000 officers in a timely manner. ${ }^{74}$ To fill the gap, the United States created a separate program to provide two to eightweek training sessions to currently serving police officers and fresh recruits. ${ }^{75}$ The first training center was in Kabul, but soon after, seven Regional Training Centers ("RTCs") were opened to provide training to police in the provinces. ${ }^{76}$ Although the U.S. program trained over 70,000 policemen by July 2007, the quality of the training received is questionable. ${ }^{77}$ Training periods were usually only a few weeks long, with no follow-up training, so trainees did not have time to absorb policing ethics from their supervisors, and they were promptly returned to their districts, where they were under the command of untrained and corrupt superiors. ${ }^{78} \mathrm{Also}$, little attention was paid to who was recruited and trained for police positions, and there was no effort made to ensure that Taliban and militia members were not recruited and trained. ${ }^{79}$

In 2005 , responsibility for the U.S. police assistance program was transferred from the Department of State to the Department of Defense. In the first two years after the move, there was little improvement in the training programs. ${ }^{80}$ However, in 2007, the U.S. launched a new training initiative called Focused District Development (FDD) under which all uniformed police in a single district were trained at the same time as a unit and placed under the supervision of a U.S. mentoring team when redeployed to their district. ${ }^{81}$ This training seems to have been more successful, as the mentoring teams were able to evaluate the unit on a variety of competencies and only pull out after it was clear that the unit was functioning professionally. ${ }^{82}$ However, the training cycles took significantly longer than originally projected, and there were severe personnel shortages. ${ }^{83}$ The major drawback of the FDD, however, was that it was administered by the U.S. military and, as a result, focused primarily on military tactics, weapons use, and counterinsurgency

\footnotetext{
73. WILDER, supra note 5 , at 29.

74. PERITO, supra note 66 , at 4 .

75. Id.

76. WILDER, supra note 5, at 29.

77. PERITO, supra note 66 , at 4 .

78. Id.

79. WILDER, supra note 5 , at 31 .

80. PERITO, supra note 66 , at 5 .

81. Id.

82. Id. at 6.

83. Id.
} 
operations, with only one week of the eight-week course spent on basic police skills. ${ }^{84}$

Two relatively simple changes could make a significant difference in the effectiveness of police training programs. First, while the FDD mentorship program addressed many of the problems in early programs, the focus of the program needs to shift away from military skills and toward basic police skills, while also providing advanced training in the areas most relevant for each district. For example, a unit in a district near the border might receive advanced training in counternarcotics, while a unit in Kabul might receive advanced training in crowd control. Second, vetting procedures, such as cross-checking trainees' names against known terrorists and militia members, should be implemented to keep Taliban and militia members out of the police and the training programs. This is a major problem for Afghanistan's police force; the fact that many police are also affiliated with independent armies is a major reason why many Afghans do not trust the police. There are also military reasons for denying Taliban and militia members access to training programs: most programs provide uniforms and equipment to the participants, so by allowing members of other armed groups into training programs, donors are actually arming Afghanistan's independent militias. ${ }^{85}$

\section{The General Population}

Poor education and illiteracy in the rural Afghan population as a whole is also problematic for Afghans trying to avail themselves of the justice system. Illiteracy potentially deters people from using the state justice system, which is based on written law. The customary legal system, which is based on a widely understood oral tradition, is probably less intimidating for illiterate Afghans. A great deal of foreign aid is already being spent to improve the educational system in Afghanistan, but very little effort is being made to address the difficulties of illiterate court users. Part of justice sector reform should include an effort to make courthouses friendlier to illiterate Afghans by providing the opportunity to file claims orally and by making sure that all of the court's communication with the parties in legal cases occurs through both oral and written mediums.

Initiatives to educate rural Afghans about their legal rights should also be broadly implemented in the provinces. Most rural Afghans are not very aware of the existence of statutory Afghan law, much less its

84. Id. at 5 .

85. See id. at 4. 
substantive provisions, ${ }^{86}$ so they have no idea if the judge deciding their case is applying the law or something very different. If Afghans were more knowledgeable about the law, they would have a better idea of whether or not judges were applying it, and thus provide valuable community oversight of the judicial officers in their district. Greater knowledge of their legal rights would also highlight the differences between Afghan statutory law and customary law, giving rural Afghans the choice to apply to the state courts if the two are in conflict.

\section{DiSTRUST OF STATE INSTITUTIONS}

There is a deep distrust of state institutions in rural Afghanistan that has its roots in historic conflict as well as in current circumstances. This distrust is well founded, since corruption pervades both the police force and the judiciary. Further decreasing trust in state institutions is the police's and judiciary's subservience to powerful local warlords and commanders, whose approval they need to remain in their positions. As a result, members of local militia commit crimes with impunity. State institutions must be made worthy of trust in order to become relevant in rural Afghanistan.

\section{A. Historical Distrust}

A perhaps apocryphal story recounts the response of an elderly tribesman to an argument in favor of a strong government: "We are content with discord, we are content with alarms, we are content with blood,'. . . but 'we will never be content with a master."87 This statement exemplifies rural Afghans' historic distrust, dislike, and disinterest in state institutions, including state justice systems. Many Afghans do not accept basic rule of law concepts such as the idea that the state has exclusive control over criminal matters. ${ }^{88}$ Many areas of Afghanistan have operated without formal government institutions for a long time and have developed their own methods of dispute resolution. ${ }^{89}$ For many in rural Afghanistan, the right and responsibility for justice resides in the person wronged or their family or tribe, not within the state. As a result, actions taken by the state system are not considered to be dispensing justice. ${ }^{90}$ Therefore, rural Afghans see punishments

86. See ESTABLISHING THE RULE OF LAW, supra note 7, at 5 .

87. TANNER, supra note 9, at 133-34 (reported by British official Mountstuart Elphinstone while leading a mission to Afghanistan in 1809).

88. Barfield, Culture and Custom, supra note 27, at 348.

89. Id.

90. Barfield, On Local Justice, supra note 26, at 439. 
imposed by the state as either inadequate, in that a settlement between the parties will have to be reached even if the perpetrator has been punished under the state system, or inappropriate because if the parties have already reached a settlement there is no need for the state to get involved. ${ }^{91}$

Central governments in Kabul have tried to impose statute-based law on rural Afghanistan for at least a century, and they have always been met with resistance, regardless of their ideological basis. ${ }^{92}$ In the 1920s, King Amanullah attempted to modernize Afghanistan by promulgating new codes that improved the status of women and made education widely available, but resistance to these reforms forced him into exile in 1929. ${ }^{93}$ When the People's Democratic Party of Afghanistan took power and tried to institute socialist reforms, including land reform and equality for women, the resistance forced the Soviet Union to invade in order to keep the government from collapsing. ${ }^{94}$ However, Afghans have not only resisted liberal reforms. Popular response to the Coalition invasion of Afghanistan in 2001 was to ask for a larger international force to provide greater security, not to rise up in support of the Taliban. ${ }^{95}$ This was because the social and religious policies that the Taliban forced on the country were unpopular in both urban and rural Afghanistan.96 Although in many ways the Taliban policies represented a fusion of traditional customary law and Shari'a law, they also introduced many policies foreign to Afghanistan, such as beard codes and bans on all forms of entertainment, which undermined their legitimacy among rural Afghans. ${ }^{97}$ Rural Afghans are content with their own customary dispute resolution methods and see attempts at state control as unnecessary, corrupt, and oppressive. ${ }^{98}$

\section{B. Current Circumstances Generate Distrust of State Institutions}

Much of rural Afghanistan's distrust of state institutions is not historic, but stems from the fact that the state system is largely corrupt. State officials operating outside of the capital or other large cities are often under the control of local power brokers. This undermines perhaps

91. Id. at 440.

92. See Barfield, Culture and Custom, supra note 27, at 348-49.

93. Id. at 349 .

94. Id.

95. Thomas J. Barfield, Problems in Establishing Legitimacy in Afghanistan, 37 IRANIAN STUD. 263, 289 (2004).

96. Barfield, A State Run by Good Muslims, supra note 28, at 232.

97. See id.

98. See Barfield, Culture and Custom, supra note 27, at 361. 
the most important tenet of the rule of law, that "the government is imbedded in a comprehensive legal framework," and government officials understand that "the law will be applied to their own conduct." 99 Judges assigned to the provinces report that they are only able to perform their duties if they remain in favor with the local commanders. ${ }^{100}$ The same pressures are also exerted on prosecutors. ${ }^{101}$ Most of the men serving as police owe their allegiance to local warlords and commanders, rather than to the central government. ${ }^{102}$

\section{Police Inefficiency and Corruption}

The armed groups that rove the countryside are responsible for many of the violent crimes committed against rural Afghans. ${ }^{103}$ Crimes committed by these groups tend to be outside the authority of the customary justice system, which operates primarily as a system of mediation and depends on the parties being susceptible to community pressure. With the state justice system co-opted by the commanders, this means that armed groups have essentially free reign to terrorize the populace. Even police not aligned with armed groups cannot act against them, because they cannot provide for their own security. ${ }^{104}$ Police admit that they will often know who is responsible for a crime, but be unable to arrest them because they are a member of an armed group. ${ }^{105}$ As a result, most Afghans do not feel there is any point in reporting crimes to the police. ${ }^{106}$

The police are widely viewed as ineffective, and distrust of the police is pervasive throughout Afghanistan for good reason, particularly in rural areas. ${ }^{107}$ Because of low and intermittent pay, the police turn to the people they are supposed to be protecting to supplement their income. ${ }^{108}$ Many Afghans report that the police operate on an "arrest, bribe, [and] release basis," 109 and a study of rural Afghan women found that the few women who were aware of a nearby police presence only knew about it because the police had arrested one of their male

99. Thomas Carothers, The Rule of Law Revival, in PROMOTING THE RULE OF LAW ABROAD: IN SEARCH OF KNOWLEDGE, supra note 3, at 3, 4.

100. See ESTABLISHING THE RULE OF LAW, supra note 7, at 7.

101. Id.

102. Id. at 10.

103. See FEINSTEIN, supra note 43 , at 50 .

104. Id. at 51.

105. Id. at 50 .

106. Id.

107. WILDER, supra note 5, at 1.

108. See FEINSTEIN, supra note 43 , at 53-54.

109. WILDER, supra note 5 , at 1. 
relatives. ${ }^{110}$ Police operate illegal roadblocks in order to extort money from truck drivers, ${ }^{111}$ significantly increasing the costs of transportation and also the costs of any goods that must be transported. Finally, Human Rights Watch has documented direct police involvement in serious crimes such as home invasion, kidnapping, and rape.112 Police have become a major cause of insecurity in Afghanistan, rather than security. ${ }^{113}$

\section{Corruption in the Judiciary}

Corruption is also pervasive in the judiciary, undermining Afghan trust in the state court system. Salaries are as low as thirty-six dollars per month and are paid intermittently, especially to judges operating in rural areas. ${ }^{114}$ There are reports that judges and prosecutors routinely ask defendants or their families for money in exchange for release from prison and accept bribes in exchange for not proceeding with specific cases. ${ }^{115}$ The Supreme Court does not seem to be effectively exercising its oversight authority over the lower courts, given the widespread reports of abuse and the relatively small number of proven cases. ${ }^{116}$ Amnesty International suggests that this is because the Supreme Court's oversight duty conflicts with its duty to nominate candidates for judicial positions. ${ }^{117}$

In addressing the problem of corruption in the police and the judiciary, it is essential to keep in mind that there are two separate problems that must be addressed: the corruption itself and the public distrust of those institutions stemming from the corruption. Therefore, anticorruption methods have a dual purpose: to stop the corruption and to ensure that the people see the government making credible attempts to solve the problem. ${ }^{118}$

Low and intermittent salaries are a major cause of corruption in the Afghan judiciary, and the government must make regular payment and

110. See FEINSTEIN, supra note 43 , at 55 .

111. Report of the Independent Expert, supra note 36, ๆ 28.

112. See Feinstein, supra note 43 , at 54 (citing Human Rights Watch, "Killing You Is A VERY EASY THING FOR Us": HUMAN RightS ABUSES IN SOUTHEAST AFGHANistaN (2003)).

113. See WILDER, supra note 5 , at 1.

114. See ESTABLISHING THE RULE OF LAW, supra note 7, at 7.

115. Amnesty Int'l, supra note 18 , at 19.

116. See id. at 21 .

117. Id. at 21-22.

118. See Madalene O'Donnell, Corruption: A Rule of Law Agenda?, in CrvIL WAR AND THE Rule of LAW: SECURITY, DEVElopmENT, HuMaN RightS 225, 227 (Agnes Hurwitz \& Reyko Huang eds., 2008). 
increased salaries a key priority for both the police and the judiciary. The country will never be able to gain control over issues such as narcotics smuggling as long as the personnel responsible for enforcement are unpaid or underpaid. However, simply increasing pay is not enough. The results of anticorruption programs in a number of countries show that while providing a dignified wage to public employees is essential, once an atmosphere of corruption pervades the agency, simply raising wages will not solve the problem. ${ }^{119}$ Therefore, wage increases should be combined with programs that monitor the performance of public servants. ${ }^{120}$

An effective monitoring system would address many of the other problems undermining public confidence in the state justice system. For example, a monitoring system set up to tackle corruption in the courts could also monitor whether the judges are correctly applying the law. The monitoring system could also check whether noneconomic corruption by local warlords is occurring and could transfer judges and police officers who appear to have been co-opted. Finally, a monitoring system could monitor for security abuses by police officers, such as "arrest, bribe, [and] release" schemes and crimes committed by the police.

Since much of the corruption stems from police and judicial cooption by local powerbrokers, monitors should rotate among different courts in different areas of the country, with no monitor spending more than a few weeks in any one location. Not only would this allow a small number of monitors to supervise courts and police offices throughout the country, but it also would prevent cooption of the monitors by local forces.

\section{DifFiculty OF TRAVELING}

The state judicial system in Afghanistan is mostly concentrated in major urban centers. ${ }^{121}$ In the provinces, there are very few courthouses outside of the provincial capitals. ${ }^{122}$ This means that Afghans in villages must travel in order to access the state justice system. ${ }^{123}$ However, travel and communication remain difficult in Afghanistan's provinces.

119. See id. at 239.

120. Id. (citing Juan Domingo Perón's observation: "People are good. But if you monitor them, they are better").

121. See McCullough, supra note 17, at 831; Ahmed, supra note 11, at 126.

122. JANE STROMSETH, DAVID WIPPMAN \& ROSA BROOKS, CAN Might MAKe Rights? BUILDING THE RULE OF LAW AFTER MILITARY INTERVENTIONS 245 (2006).

123. See McCullough, supra note 17 , at 831 . 
Almost seventy-five percent of roads are unpaved ${ }^{124}$ and over two decades of war waged over Afghan soil has left unexploded landmines littering the countryside. In addition, local bandits, police, and warlords have set up numerous "toll stations" on major roads, making travel dangerous and expensive. All of these factors make physical access to state justice systems more difficult.

Landmines are a consistent threat to security in rural Afghanistan. ${ }^{125}$ Many rural Afghans are forced to severely constrain their movements to avoid unexploded mines. ${ }^{126}$ Although the greatest effect of the landmines is in restricting access to pasture, landmines also restrict access to vital community resources, such as schools, clinics, and courts. ${ }^{127}$ Afghan civilians must weigh the need to travel against the danger from landmines. ${ }^{128}$ Given these dangers, it is unsurprising that most Afghans prefer to rely on local customary justice systems over the state justice system.

For women, these universal dangers are compounded by cultural norms that prevent women from traveling outside of their homes alone. This is particularly detrimental because women as a group have the most to gain from access to the state justice system. Although the Afghan justice system has been criticized by Western scholars as discriminatory to women, it nonetheless is a vast improvement over the customary justice systems, which shut women out entirely. The norms that prevent women from traveling alone mean that a woman who wants a divorce, a remedy not available under traditional Afghan law, ${ }^{129}$ must either ask her husband or another male relative to accompany her to the courthouse or face extreme danger by attempting to make the trip herself. As a result, most rural women are cut off from the few legal remedies afforded to them under Afghan and Islamic law by their inability to access the state justice system that could provide those remedies.

The danger and difficulty of traveling in rural areas not only hampers the ability of rural residents to get to the courts, but it also hinders the smooth functioning of the courts. Many judges and prosecutors in rural areas go without payment for months at a time not as the result of a lack of funds, but rather because there is no safe way

124. Central Intelligence Agency, The World FactBooK, https:/www.cia.gov/ library/publications/the-world-factbook/geos/af.html (last visited Feb. 10, 2011).

125. See FEINSTEIN, supra note 43 , at 46.

126. Id. at 48 .

127. Id. at $46-47$.

128. See id. at 46-48.

129. See Fatima Gailani, Human Rights in Afghanistan: Law and Reality, in THE RULE OF LAW IN THE MIDDLE EAST AND THE ISLAMIC WORLD: HUMAN RIGHTS AND THE JUDICIAL Process 144, 148 (Eugene Cotran \& Mai Yamani eds., 2000). 
to deliver payment. ${ }^{130}$ The situation created by a lack of payment for months, and low payment when it does arrive creates fertile ground for corruption. ${ }^{131}$ Provincial judges also have little to no access to legal texts, and therefore make decisions largely without reference to the law. ${ }^{132}$ Finally, there is little to no monitoring of provincial courts, and visitors to the provinces have reported little to no activity at certain courthouses.133 Thus, rural Afghans face the possibility of making a long and dangerous trip to the nearest court, only to discover that the court is not in operation.

The solution to the difficulty of traveling in rural Afghanistan is simple to state but difficult to actually implement. The Afghan government and the NATO forces in Afghanistan must secure the country against independent armed forces and disable or safely detonate the landmines that litter the countryside. Defeating or disarming the Taliban and other independent militias terrorizing the Afghan people is easier said than done and remains the focus of most of the international community's current efforts in Afghanistan. However, a strong, coordinated effort to disarm or safely detonate landmines would probably have a positive impact far beyond its military benefits. Countrywide, rural Afghans report that their access to pastureland is most negatively impacted by the presence of landmines. ${ }^{134}$ Therefore, a program to eradicate land mines would not only increase the ability of Afghans to access courts, medical clinics, and schools, but would also increase their access to livelihoods other than poppy production. Finally, such a program would also generate good will on the part of the populace, something that cannot be given too much weight in a war that is being fought "in the hearts and minds" of Afghans as well as on the battlefield.

The secondary effects of the danger on the roads must also be addressed. Every effort should be made to ensure that judges get paid regularly and are supplied with the basic legal materials necessary for them to administer the law. A judiciary with inadequate resources is more likely to decide cases on the basis of external pressure, corruption, and intimidation. ${ }^{135}$ Adequate and regular pay will greatly decrease the incentives to take bribes and will at least provide judges with financial independence from local power brokers. Corruption and allegiance to local power brokers among judges leave little incentive for rural

130. Amnesty Int'1, supra note 18 , at 20 .

131. See ESTABLISHING THE RULE OF LAW, supra note 7, at 7.

132. Id.

133. Id.

134. See FEINSTEIN, supra note 43 , at 46 .

135. STROMSETH ET AL., supra note 122 , at 240. 
Afghans to seek relief from the state justice system rather than from their own customary legal systems. Lack of basic legal resources such as legal codes and higher court decisions has a two-fold effect on the judiciary; it leads judges to make decisions without reference to the law, and it can "undermine respect for the judiciary both in the judges' own eyes and in the eyes of the public." 136

Finally, the difficulty that Afghan citizens have in getting to the courts could be solved by having the courts come to them. Mobile court systems have been used with success in refugee camps in Kenya and Zambia. ${ }^{137}$ In Afghanistan, a mobile court system could also solve the problem of judges being co-opted by regional power brokers. If judges do not remain in one area for long, and if they are guarded the entire time they are in that area, it will be more difficult for regional warlords and commanders to bribe or intimidate them. Judges will also be less likely to develop biases for or against prominent members of the community in each region.

\section{CONCLUSION}

The rule of law is a universal good, necessary for everything from freedom, to democracy, to economic stability. 138 But most Afghan citizens today do not live under a rule of law regime. While laws exist, in the sense that they have been codified, very few judges know the laws and fewer still apply them. The success of the current international military presence in Afghanistan will be measured by the country's stability after the military leaves. Stability cannot exist in a country that does not live under the rule of law.

Afghanistan will never have a rule of law society until the seventyfive percent of its population that lives in rural areas has access to the state institutions that administer the law. Currently, physical, practical, and cultural obstacles prevent the vast majority of Afghans from accessing those systems. In order for the rule of law to prevail in Afghanistan, the judiciary and police must be taught about the law and trained in how to administer it. Both institutions must be purged of corruption and protected from the influences of powerful warlords and

136. Id. at 241 .

137. See UNHCR, GLOBAL REPORT 2007 - ZAMBIA 289 (noting that mobile courts have been particularly effective at protecting the rights of rape and abuse survivors); UNHCR, Operational Protection in Camps and SeTTlements: A Reference Guide of Good Practices in the Protection of Refugees and Other Persons of ConCERn, at A11A12 (2006).

138. See Brian Z. Tamanaha, On the Rule of Law: History, Politics, AND Theory 2 (2004); Kleinfeld, supra note 3, at 31-32. 
politicians. Rural Afghans must be able to get to the state courthouses and utilize the court system. These goals are not impossible, but in order for them to be accomplished, they require commitment and coordination from the international community and the government of Afghanistan. 